\title{
Use of Catchment Physiographic Factors in Selection of Design Storm and its Effect on Floods Estimated for Ungauged Catchments
}

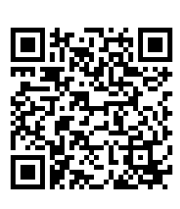

\author{
Annapurna Patra C Ramesh and N Vivekanandan* \\ Annapurna Patra C Ramesh and N Vivekanandan* \\ Submission: September 23, 2019; Published: October 10, 2019 \\ *Corresponding author: N Vivekanandan, Central Water and Power Research Station, Pune, Maharashtra, India
}

\begin{abstract}
Reliable estimation of high and low flow events in rivers or streams at any ungauged watershed location are essential for making strategic and informed decisions. This is required when the civil works such as flood protection works, and design of hydraulic structures are being planned on river stretches. Wherever data is not available on rivers/ streams, hydrological models (empirical, conceptual and/or probabilistic) act as important tools to establish baseline characteristics for determining the longterm impacts. In the present study, river protection works are planned on river Sirsa and its tributaries for which observed flood records are not available. As the protection works depend on the intensity of flood at the location of interest, flood estimation assumes vital role. Thus, a systematic analysis of catchment factors followed by estimation of design storm duration and design storm depth from the extreme value analysis of daily rainfall is carried out. The selection of storm depths for the design storm durations was carried out for desired return periods for catchments through a physiographic analysis. Evaluation of flood estimate is made with hydrologic analysis where scanty data made available for the study. A typical case of time compensation for the storm depth estimation adopted for flood estimation along the Sirsa river stretch is presented to depict the hydrologic time scale effects of rainfall on runoff transformation process.
\end{abstract}

Keywords: Catchment; Design flood; Design storm; Hydrologic analysis; Physiographic factors; Rainfall depth; Rational formula; Runoff; Time of concentration

\section{Introduction}

Hydraulic designs in river engineering are composed of two main aspects such as flood estimation and channel sizing which are essential for safe flood conveyance. Prediction of runoff water in an ungauged catchment area is vital for various practical applications such as design of drainage structure, flood defenses, flood protection works, inflow forecasting and for catchment management tasks (say water allocation) and climate impact analysis. Almost all hydrologic analyses require one or more time-scale parameters as input. Out of this, time of concentration $\left(t_{c}\right)$ is the most frequently utilized time parameter [1]. However, modelers are often confused by the number of estimation methods of $t_{c}$ and often select a method without evaluating and comparing its accuracy with other methods [1,2]. For instance, the design of urban storm water drainage systems using the rational method requires an estimate of $t_{c}$ for selecting the design rainfall intensity from the Intensity-Duration-Frequency curves [3]. A study on modifying available equations on estimation of $t_{c}$ to minimize their bias for any particular region of interest was attempted and the methods such as California, Kirpich, Arizona Department of Transport, NRCS were applied to 72 watersheds and sub-watersheds in Khorasan Razavi province, Iran [4] wherein ranking-based selection was adopted for the best performing method.

A number of methods viz, [5-7], conceptual (lumped and distributed), stochastic and probabilistic approaches are generally adopted for estimation of peak flood. The conceptual and probabilistic approaches require observed data to calibrate and validate the model being employed. There are well established conceptual and probabilistic methods for flood estimation [8-9].

Design floods for a given location at a river/ stream can be estimated by flood frequency statistics and using design storm method which when applied to the same catchment often provide quite different results [10]. The Road Construction Authority of Victoria (RCA) has carried out a study to evaluate the design flood estimations for water ways, wherein the rational method was critically examined [11]. In the said study small, medium and 
large catchments were considered as candidates, for which the upper limits of $25 \mathrm{~km}^{2}, 250 \mathrm{~km}^{2}$ and $1000 \mathrm{~km}^{2}$ respectively were taken as general guidelines. The case studies carried out on time of concentration paradox [12] indicates that available approaches for the estimation of the time of concentration may yield numerical predictions that differ from each other by up to 500\%. It was demonstrated [5] that large errors in peak discharge estimates at catchment scales can be ascribed to errors in the estimation of catchment response time i.e., time of concentration $\left(\mathrm{t}_{\mathrm{c}}\right)$ and time to peak $\left(\mathrm{t}_{\mathrm{p}}\right)$ which hints at development of alternative approach to estimate representative response times. Flood estimation in small catchments is difficult since

a. Flood peaks are more susceptible to the influence of local features, [13].

b. Local extreme precipitation events.

c. Appropriately describing the local hydrological processes crucial for reliable flood estimation is not easy, as flood generation can be dominated by few processes compared to larger catchments where an averaging of processes over a larger spatial area takes place [14].

d. Local land use changes might have significant effects on the hydrological processes and observed data should furthermore be available in high temporal resolution.

The present paper attempts to present the flood estimation work carried out for ungauged catchments using the catchment analysis, Extreme Value Analysis (EVA) of rainfall and selection of design storm depths for catchments based on their catchment factors. A typical case of effect of physio graphically selected design storm on flood estimation along the river at selected reaches has also been analyzed.

\section{Study Area and Data used}

The study area falls in the river basin of Satluj and in particular Sirsa, a tributary to Satluj in Himachal Pradesh (latitude $30^{\circ} 48^{\prime} \mathrm{N}$ to $31^{\circ} 15^{\prime} \mathrm{N}$ and longitude $76^{\circ} 34^{\prime} \mathrm{E}$ to $76^{\circ} 58^{\prime} \mathrm{E}$ ) in the Nalagarh valley. The rivers/ streams being studied (Sirsa, Balad, Kundlu, Kanahan, Baircha, Sandholi, Khera, Ratta and Manpura) have small to medium catchment areas, say $4.65 \mathrm{~km}^{2}$ (Satiwal Nadi) and $113 \mathrm{~km}^{2}$ (Balad Nadi) and on Sirsa limb the catchment area ranges from $241 \mathrm{~km}^{2}$ at RD (Reduced Distance) 28300 to $531 \mathrm{~km}^{2}$ at RD 0 . Most of these streams are westerly or northwesterly flowing. In the present study, a contiguous reach of Sirsa from RD 28300 to RD 0 has been considered to analyses the physiographic effects on design storm selection for the catchments. For the catchment analysis of rivers/ streams Survey of India toposheets (53A, 53B, $53 \mathrm{~B} / 9,53 \mathrm{~B} / 13$ and 53A/16) were used. Index map showing rivers, tributaries and streams in the study area is presented in Figure 1. From the index map it could be observed that the river system of Sirsa has tributaries predominantly on the right bank except one (Kanahan) on left bank and the drainage density and length of rivers are highly variable.

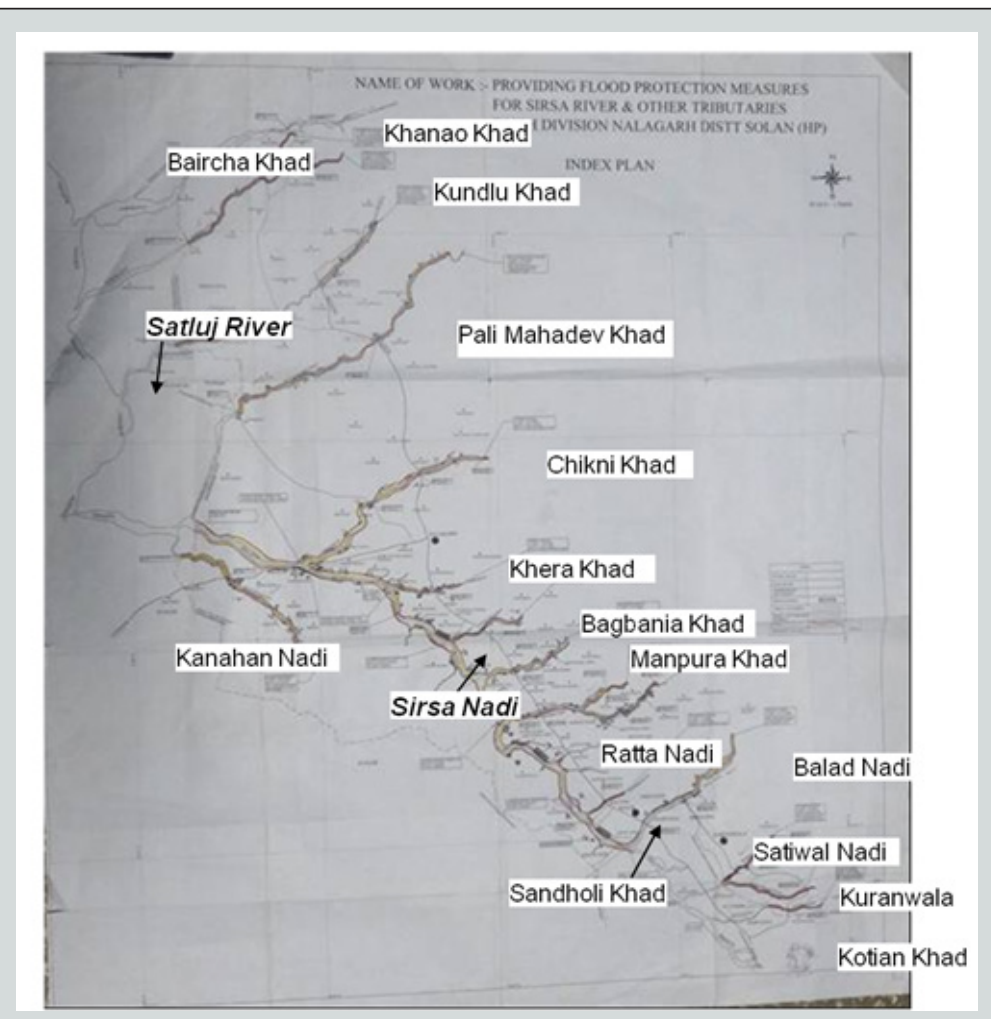

Figure 1: Index map showing Satluj-Sirsa Rivers (with tributaries) in study area. 


\section{Civil Engineering Research Journal}

In the areas underlain by high hill ranges, the valleys are narrow and deep with steep slopes trending in NW-SE direction [15]. The stone and boulders in this area generally comprise of granite and quartzite derived from the rocks of Gneisses and Schist in the catchment area. The soil cover is generally sandy loam in valley areas of the Nalgarh district [15]and in rest of the hilly and mountainous areas, soil is skeletal. Thus, the depth of soil is generally shallow and deficient in organic matter, except in areas having good vegetative cover. The region of study has forest covers in lower valleys with scanty bushes in the ridges [15]. Flood discharge data was not available for the river/ streams in study reach as none of them was gauged. Only, the catchment area of rivers/ streams and daily rainfall data for the period 1991 to 2015 (with a gap of 2004 and 2005) for Kasauli rain gauge station was available for the study.

\section{Method of Approach}

Study involves the flood estimation for ungauged catchments wherein empirical approaches were adopted which is interwoven with catchment hydrologic concepts. The method of approach adopted in the study is briefly given as below;

i. Perform the catchment analysis and extract the physiographic factors for the river/ stream from the Survey of India (SoI) toposheets of the region.

ii. Conduct EVA of rainfall data to estimate extreme 1-day rainfall for different return periods.

iii. Estimate $t_{c}$ and lag time $\left(t_{L}\right)$ for each of catchment from physiographic factors and use them in selecting design storm duration for each of the catchments.

iv. From EVA results of daily rainfall data, estimate storms of different durations (1-hour, 2-hour, 3-hour, 4-hour, 5-hour and 6-hour) based on the design storm period as required for catchments

v. Use the storm depth obtained from EVA of rainfall to estimate the peak flood (design flood) for each of the catchment for different return period.

vi. Evaluate the design flood with hydrologic analysis and/ or available information on floods or high flood records for the catchments.

\section{Flood Estimation for Ungauged Catchments}

A review of runoff methods and design storm estimation methods was carried out $[5,10,11]$ based on which the rational formula was selected for flood estimation. The main factors that affect the runoff generation process $[1,16]$ in a catchment are rainfall, meteorology, catchment physiography and storage. The design sequence of flood estimation in the study involves following six steps viz.

i. Catchment analysis for estimation of physiographic factors

\section{ii. EVA of daily rainfall}

iii. Estimation of time of concentration and lag time of catchments

iv. Determination of runoff coefficient for catchments

v. Estimation of storm duration and rainfall depth for each of the catchment and

vi. Estimation of peak flood and evaluation of results with evidenced data.

\section{Catchment Analysis for Estimation of Physiographic Factors}

The physiographic factors that affect the runoff generation process in a catchment is; size, shape, slope, landuse, soil cover, drainage network, land cover management practices, altitude and geology. In case of small catchments, the storage factors and meteorological factors are usually negligible in runoff generation, thus physiographic factors (area of catchment, slope and shape; stream lengths) along with the rainfall factor (depth and duration) play a decisive role.

Drainage area shape is instrumental in governing the rate at which water is supplied to the mainstream as it precedes the channel flows reaching the outlet. It is, therefore, a significant feature which influences the period of rise in catchment flows. $[1,5]$. In general, a semicircular basin in which the flow converges from all points to the outlet will define a hydrograph with a shorter time to peak than one produced on a long narrow basin of equal area. Generally, the land slope has a complex relationship to the surface runoff because of its influence on infiltration, soil moisture content and vegetative growth. The influence of land slope on hydrograph shape is manifested in the time of concentration [15] which has effect on runoff volumes to defined stream channels. For smaller catchment areas the overland flow regime may exert a dominating effect on the time relationships and the peak of the hydrograph while it is converse for larger catchments where channel processes dominate.

\section{EVA of Daily Rainfall}

Design flood estimation may be performed by EVA of observed daily rainfall where these are available and adequate in both length and quality. Using observed data in rainfall frequency estimation assumes that the data are stationary. The procedure for EVA of daily rainfall involves selecting and fitting an appropriate theoretical probability distribution to the data. In India, the widely used probability distribution $[17,18]$ for EVA of rainfall and flood discharge data is Extreme Value Type-1 (EV1), commonly known as Gumbel distribution and therefore adopted in the present study. The mathematical form of cumulative distribution function of EV1 is given as below:

$$
\begin{gathered}
F(x)=\exp \{-\exp [-(x-\alpha) / m]\} \\
-\infty<\mathrm{x}<\infty,-\infty<\alpha<\infty, \mathrm{m}>0 \ldots \text { (1) }
\end{gathered}
$$


where, $\alpha$ and $m$ are the location and scale parameters of the distribution. The parameters $\alpha$ and $\mathrm{m}$ can be estimated by Maximum Likelihood Method (MLM), which requires an iterative method that can be implemented by using computer-oriented procedures. The maximum likelihood estimates $\alpha^{*}$ and $\mathrm{m}^{*}$ of EV1 are given by:

$$
\begin{aligned}
& \mathrm{m}^{*}=\sum_{\mathrm{i}=1}^{\mathrm{n}}\left(\mathrm{x}_{\mathrm{i}} / \mathrm{n}\right)-\left[\sum_{\mathrm{i}=1}^{\mathrm{n}} \mathrm{x}_{\mathrm{i}} \exp \left(-\mathrm{x}_{\mathrm{i}} / \mathrm{m}\right) / \sum_{\mathrm{i}=1}^{\mathrm{n}} \exp \left(-\mathrm{x}_{\mathrm{i}} / \mathrm{m}^{*}\right)\right] \\
& \alpha^{*}=-\mathrm{m}^{*} \ln \left[\sum_{\mathrm{i}=1}^{\mathrm{n}} \exp \left(-\mathrm{x}_{\mathrm{i}} / \mathrm{m}^{*}\right) / \mathrm{n}\right] \quad \ldots \text { (3) }
\end{aligned}
$$

The desired parameters are further used to estimate the extreme rainfall $\mathrm{X}_{\mathrm{T}}$ for different return periods as given by:

$$
\mathrm{X}_{\mathrm{T}}=\alpha^{*}+\mathrm{Y}_{\mathrm{T}} \mathrm{m}^{*} \text { where } \mathrm{Y}_{\mathrm{T}}=-\ln (-\ln (1-(1 / \mathrm{T})))
$$

where, $\alpha^{*}$ and $m^{*}$ are the estimates of location and scale parameters of the distribution, $\mathrm{n}$ is the number of sample values, $\mathrm{T}$ is the return period (year), $\mathrm{x}_{\mathrm{i}}$ is the variable (i.e., rainfall) and $\mathrm{Y}_{T}$ is the reduced variate.

\section{Estimation of Time of Concentration and Lag Time of Catchments}

In estimation of design storm duration of any catchment, the time of concentration or lag times are used. Time of concentration $\left(t_{c}\right)$ is used in hydrology to measure the response of a watershed to a rain event .i.e. the time required for runoff, as a result of effective rainfall, with a uniform spatial and temporal distribution over a catchment, to contribute to the peak discharge at the catchment outlet [19]. $t_{c}$ is a function of topography, soil and land use within the watershed and $t_{c}$ of a catchment varies from season to season and from storm to storm. Various methods have been proposed by researchers $[1,2,19-22]$ to estimate $t_{c^{\prime}}$. In the present study, three typical methods (in SI units) are used, which are given as below:

Kirpich:

$$
\mathrm{t}_{\mathrm{c}}=0.0195 \mathrm{~L}^{0.770} \mathrm{~S}^{-0.385}
$$

Kerby:

$$
\mathrm{t}_{\mathrm{c}}=1.44\left(\mathrm{L \eta S}^{-0.5}\right)^{0.467}
$$

California Culvert:

$$
\mathrm{t}_{\mathrm{c}}=\left(0.871 \mathrm{~L}^{3} / \Delta \mathrm{H}\right)^{0.385}
$$

where, $t_{c}$ is time of concentration of catchment (hour), $L$ is length of longest stream $(\mathrm{km}), \eta$ roughness coefficient, $\mathrm{S}$ is average slope of catchment and $\Delta \mathrm{H}$ is difference (upstreamdownstream) in elevation (m), thus each of the above formula uses $\mathrm{L}$ and $\mathrm{H}$ (or slope).To overcome the variations in $\mathrm{t}_{\mathrm{c}}$ estimates the mean from these three have been adopted in finalizing the $t_{c}$ of a particular catchment. The catchment physiographic factors along with mean $\mathrm{t}_{\mathrm{c}}$ are presented in Table 1.

Lag time of a catchment is the time interval from the center of mass of rainfall excess to the peak of the resulting hydrograph. Researchers [23] have established a relationship between $t_{c}$ and $t_{L}$ for average natural watershed conditions with uniform distribution of runoff as below:

$t_{L}=0.6 t_{c}$

where, $t_{L}$ is catchment lag time (hour). Consequently, $t_{L}$ for catchments could also be found by other methods using geomorphic factors (say, from time to peak $\left(t_{p}\right)$ ).

\section{Determination of Runoff Coefficient for Catchments}

Runoff coefficient (C) is an empirically determined constant, which is dependent on the nature of the drainage surface area. An impervious surface (concrete surface) clay soil will have a relatively high runoff coefficient closer to 1 , on the other hand a sandy soil would have a lower runoff coefficient. In addition to the nature of the surface and the soil, the slope of the drainage area and land use has an effect on the runoff coefficient. Thus for transformation of rainfall striking over a catchment to runoff, the $\mathrm{C}$ should be selected rationally considering the terrain attributes (land use, soils and slope-lengths).

\section{Estimation of Storm Duration and Rainfall Depth}

The design rainfall intensity is a vital factor in calculating peak runoff rate is the constant storm intensity having the specified design return period and duration equal to ${ }_{c}$ and for certain specific needs the storm duration would be for peak flood estimations it is equal to $t_{L}$ of the catchment. Once values for design return period and duration are available, the design rainfall intensity can be determined from an appropriate intensity-duration-frequency graph or storm analysis of the region.

\section{Estimation of Peak Flood}

Estimation of runoff for a catchment is a complex and nonlinear process as it depends on many factors like the rainfall depth and duration, rainfall pattern, catchment physiographic factors such as soil cover, land use, ground permeability, etc. [6-8]. For design and planning purposes of civil works on rivers/ streams, the peak flood estimation generally is carried out using rational method. The mathematical form of rational formula used in estimation of peak flood is given as below;

$$
t_{L}=0.6 t_{c}
$$

where, q is peak flood $\left(\mathrm{m}^{3} / \mathrm{s}\right), \mathrm{C}$ is runoff coefficient, $\mathrm{i}$ is rainfall intensity (mm/hour) occurring uniformly over the catchment for a period of $\mathrm{t}_{\mathrm{c}}$ or more and $\mathrm{A}$ is area of catchment $\left(\mathrm{km}^{2}\right)$. The accuracy of flood peak estimations adopting rational formula for a catchment adopting rational method depends on selection of proper runoff coefficient and design storm intensity thus these play a crucial role in flood estimation.

\section{Results and Discussions}

In the present study, the flood estimation for the ungauged catchments are assessed through the catchment physiographic analysis, rainfall analysis, storm depth, rainfall-runoff response 


\section{Civil Engineering Research Journal}

factor and adopting the rational method. From Table 1, it could be observed that the ranges of catchments selected for the study span over small (Satiwal Nadi, Khanao Khad, Kurnwala Khad,
Khera Khad), medium (Baircha Nadi, Kanahan Nadi, Kundlu Khad, Chikni Khad, Balad Nadi) and large (Sirsa at RD 0 to RD 28300) types.

Table 1: Catchment physiographic factors and estimated time of concentration.

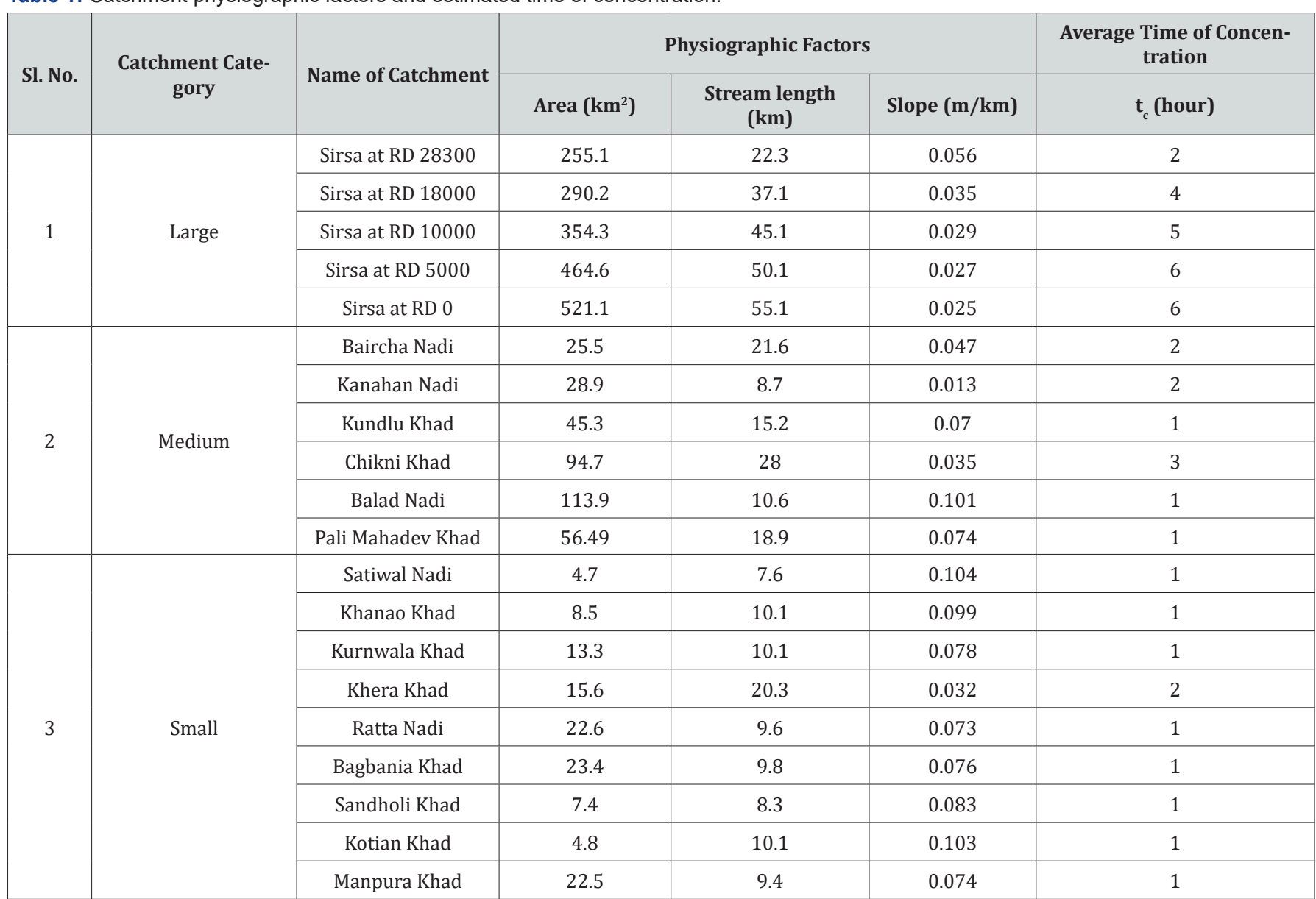

\section{Estimation of Runoff Coefficient}

The study catchments are spread over a range of drainage areas in the Nalgarh district in the same river valley i.e., Sirsa and more or less have a homogeneous catchment property. Based on a study of literature [15] on physiography of region, toposheets and land use maps a uniform runoff coefficient value of 0.55 has been adopted for the catchments of the study.

\section{EVA of Daily Rainfall Data}

Daily rainfall data was available for Kasauli rain gauge station for a period of 13 years. From this, the annual 1-day maximum rainfall series was extracted and used for EVA by adopting Gumbel probability distribution. The estimated extreme 1-day rainfall with $95 \%$ confidence limits for different return periods is presented in Table 2.

Table 2: Storm depth $(\mathrm{mm})$ for different storm duration.

\begin{tabular}{|c|c|c|c|c|}
\hline \multirow{2}{*}{ Storm Duration (hour) } & \multicolumn{3}{|c|}{ Storm Depth (mm) for } & \multirow{2}{*}{ Name of the Catchment } \\
\hline & 25-year & 50-year & 100-year & \\
\hline 1 & 85.1 & 97.1 & 109.1 & $\begin{array}{l}\text { Bagbania Khad, Kanahan Nadi, Khera Khad, Satiwal Nadi, } \\
\text { Sandholi Khad, Kundlu Khad, Kotian Khad, Baircha Nadi, } \\
\text { Kurnwala Khad, Manpura Khad, Khanao Khad, Ratta Nadi, } \\
\text { Pali Mahadev Khad }\end{array}$ \\
\hline 2 & 110.1 & 125.7 & 141.1 & Balad Nadi, Chikni Khad \\
\hline 3 & 120.1 & 137.1 & 154 & Sirsa at RD 28300 \\
\hline 5 & 130.1 & 148.5 & 166.8 & Sirsa at RD18000 and RD 10000 \\
\hline 6 & 139.1 & 158.8 & 178.3 & Sirsa at RD 0 and RD 5000 \\
\hline
\end{tabular}




\section{Civil Engineering Research Journal}

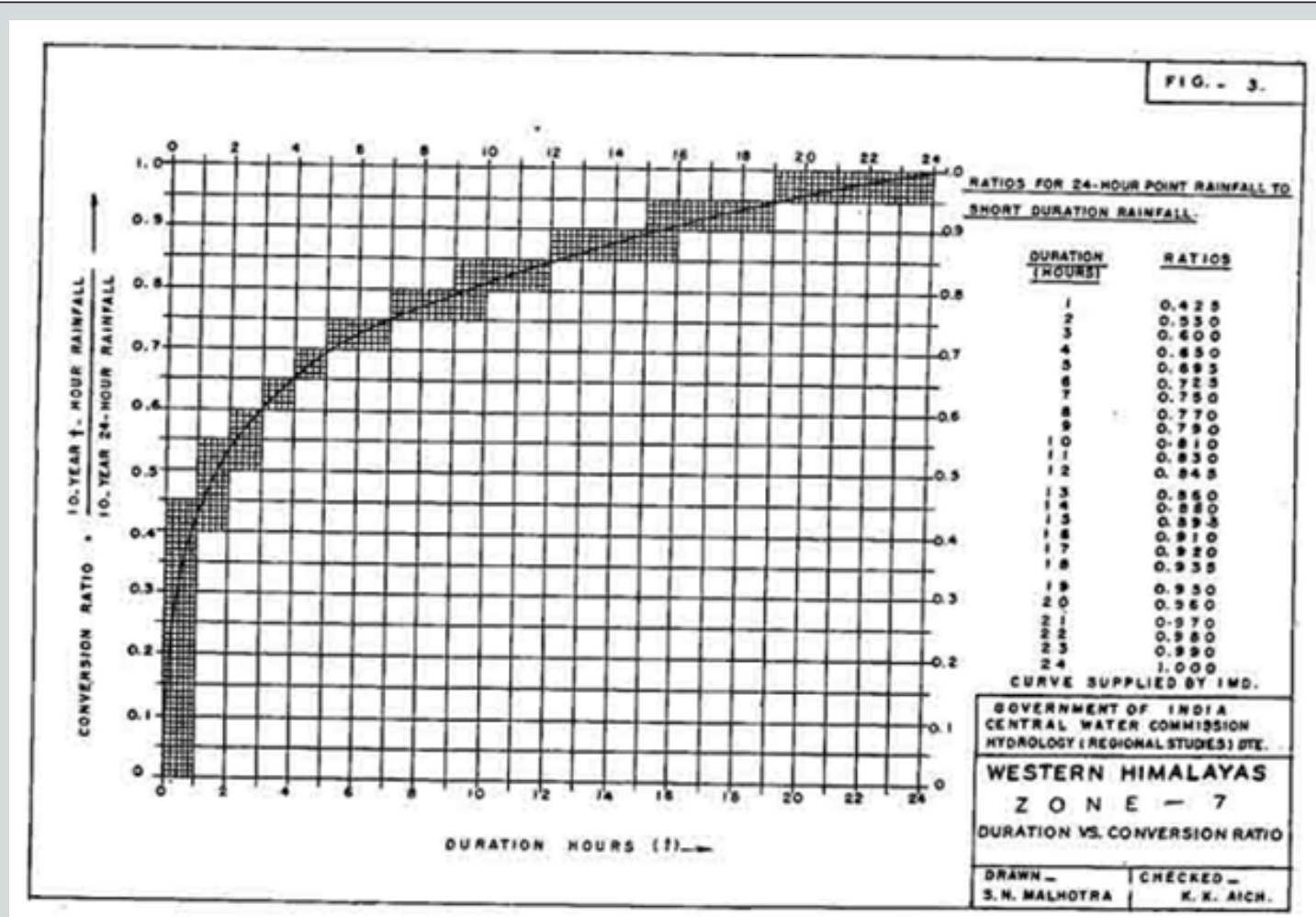

Figure 2: Conversion factor for computation of distributed rainfall for shorter duration.

Table 3: Estimated 1-day extreme rainfall with confidence limits for different return periods for Kasauli.

\begin{tabular}{|c|c|c|c|c|}
\hline \multirow{2}{*}{ Return Period (year) } & Estimated Rainfall (mm) & Standard Error (mm) & \multicolumn{2}{|c|}{ Confidence Limits at 95\% level } \\
\cline { 3 - 5 } & & & Lower limit (mm) & Upper limit (mm) \\
\hline 1.01 & 9.9 & 4.8 & 0.5 & 19.3 \\
\hline 2 & 86.2 & 9.8 & 66.9 & 105.5 \\
\hline 5 & 131.8 & 15.1 & 102.2 & 200 \\
\hline 10 & 162 & 19.4 & 144.5 & 237.5 \\
\hline 20 & 191 & 23.7 & 150.9 & 249.4 \\
\hline 25 & 200.2 & 25.2 & 170.6 & 286.3 \\
\hline 100 & 228.5 & 29.5 & 190.1 & 323 \\
\hline
\end{tabular}

\section{Selection of Design Storm for Catchments}

In the flood estimations, the catchment response in terms of $t_{c}$ has been used in assessment of design storm duration $\left(t_{d}\right)$. The $t_{d}$ derived for the different catchments are 1-hour, 2-hour, 3-hour, 4-hour, 5-hour and 6-hour which are presented in Table 2. Further in considering of $t_{c}$ for arriving at $t_{d}$, the base assumption of rainfall intensity of rational formula ' $i$ ' is the important parameter. It is to state that, the shorter duration rainfall (say, 1-hour) were not available for the study area. Based on the design storm durations, the appropriate storm depths (2-hour, 3-hour, 4-hour, 5-hour and 6-hour) were estimated adopting the procedures as detailed in CWC reports [24]. These were used for computing the design storm depths for the respective catchments from the estimated 1-day extreme rainfall (25-year, 50-year and 100-year return period) by using suitable conversion factors (Figure 2), as given in Central Water Commission Report titled 'Flood estimation report for Western Himalayas-Zone 7' [24]. The design storm duration is adopted in estimating the design storm depths from the EVA results of daily rainfall (Table 2 ) for selected design period (return period) i.e., 25-year, 50-year and 100-year. The design storm duration along with the design storm depths for selected return periods is presented in Table 3 .

In absence of any observed rainfall intensities in the region of study, the design storm depths for the first hour of the storm events of 2-hour, 3-hour, 5-hour and 6-hour has been chosen as the design rainfall intensity. It could be seen that, determination 


\section{Civil Engineering Research Journal}

of value of rainfall intensity is the most complicated part of using the rational formula.

\section{Estimation of Peak Flood for Ungauged Catchments}

The estimated design storm intensities for the catchments are presented in Table 4. The design storm rainfall intensity is used in estimating the peak flood from the respective catchment. The estimated peak flood for the river/ streams is presented in Table 4.

The approach of selection design storm duration based on $t_{c}$ need hydrologic judgments when used for the different reaches along the stretch of river. For example, consider the reach of Sirsa at RD 5000 and RD 10000 where the $t_{c}$ estimates are 5 hour and 6 hour. In this case as the storm duration was rounded which yielded a higher flood for Sirsa at RD 10000 (upstream) compared to Sirsa at RD 5000 (downstream). This is due to longer duration storm which reduces the hourly slicing of storm depth. In reality this should be other way round. In this situation, the hydrologic judgments were used, and the storm depths were time scaled for Sirsa at RD 10000 based on its time component which could be observed from $3 \mathrm{a}$ (raw output) and $3 \mathrm{~b}$ (time compensated output) in Table 4

Table 4: Estimated rainfall intensity and peak flood for the river/ streams.

\begin{tabular}{|c|c|c|c|c|c|c|c|}
\hline \multirow{3}{*}{$\begin{array}{l}\text { Sl. } \\
\text { No. }\end{array}$} & \multirow{3}{*}{ Name of the Catchment } & \multicolumn{6}{|c|}{ Rainfall Intensity and Peak Flood } \\
\hline & & \multicolumn{2}{|c|}{ 25-year } & \multirow{2}{*}{$\frac{\text { 50-year }}{\mathrm{I}_{50}(\mathrm{~mm} / \mathrm{hour})}$} & \multirow[b]{2}{*}{$\begin{array}{c}Q_{50} \\
\left(m^{3} / s\right)\end{array}$} & \multirow{2}{*}{$\begin{array}{c}100 \text {-year } \\
\mathrm{I}_{100}(\mathrm{~mm} / \text { hour })\end{array}$} & \multirow[b]{2}{*}{$\begin{array}{c}Q_{100} \\
\left(\mathrm{~m}^{3} / \mathrm{s}\right)\end{array}$} \\
\hline & & $\mathrm{I}_{25}(\mathrm{~mm} /$ hour $)$ & $\begin{array}{c}Q_{25} \\
\left(\mathrm{~m}^{3} / \mathrm{s}\right)\end{array}$ & & & & \\
\hline 1 & Sirsa at RD 28300 & 85.1 & 3408.2 & 97.1 & 3890 & 109.1 & 4368.4 \\
\hline 2 & Sirsa at RD 18000 & 85.1 & 3580.2 & 97.1 & 4085.3 & 109.1 & 4587.7 \\
\hline \multirow{2}{*}{3} & Sirsa at RD 10000 (Raw output) & 77.9 & 4221.3 & 131.5 & 4818 & 99.9 & 5410.4 \\
\hline & $\begin{array}{c}\text { Sirsa at RD } 10000 \text { (Compensated } \\
\text { output) }\end{array}$ & 92.5 & 3769 & 105.6 & 4301.7 & 118.5 & 4830.8 \\
\hline 4 & Sirsa at RD 5000 & 92.5 & 3918.4 & 105.6 & 4472.1 & 118.5 & 5022.1 \\
\hline 5 & Sirsa at RD 0 & 85.1 & 4394.8 & 97.1 & 5015.9 & 109.1 & 5632.7 \\
\hline 6 & Chikni Khad & 92.5 & 1270.1 & 105.6 & 1449.8 & 118.5 & 1628.1 \\
\hline 7 & Khera Khad & 85.1 & 220 & 97.1 & 251.2 & 109.1 & 282 \\
\hline 8 & Bagbania Khad & 85.1 & 304 & 97.1 & 346.9 & 109.1 & 389.6 \\
\hline 9 & Manpura Khad & 85.1 & 293 & 97.1 & 334.5 & 109.1 & 375.6 \\
\hline 10 & Ratta Nadi & 85.1 & 294.1 & 97.1 & 335.7 & 109.1 & 376.9 \\
\hline 11 & Sandholi Khad & 92.5 & 96.2 & 105.6 & 109.9 & 118.5 & 123.4 \\
\hline 12 & Pali Mahadev & 80.7 & 734.7 & 92.1 & 838.6 & 103.4 & 941.8 \\
\hline 13 & Balad Nadi & 77.9 & 1482.2 & 88.9 & 1691.7 & 89.2 & 1899.7 \\
\hline 14 & Kanahan Nadi & 55.2 & 409.1 & 63 & 467 & 70.7 & 524.4 \\
\hline 15 & Kundlu Khad & 92.5 & 588.8 & 105.6 & 672 & 118.5 & 754.7 \\
\hline 16 & Baircha Nadi & 85.1 & 360.6 & 97.1 & 411.6 & 109.1 & 462.2 \\
\hline 17 & Khanao Khad & 85.1 & 110.8 & 97.1 & 126.5 & 109.1 & 142.1 \\
\hline 18 & Satiwal Nadi & 85.1 & 60.5 & 97.1 & 69.1 & 109.1 & 77.5 \\
\hline 19 & Kurunwala Khad & 85.1 & 173.2 & 97.1 & 197.6 & 109.1 & 221.9 \\
\hline 20 & Kotian Khad & 85.1 & 62.7 & 97.1 & 71.6 & 109.1 & 80.4 \\
\hline
\end{tabular}

( $I_{25}$ is 25-year return period rainfall intensity; $Q_{25}$ is 25-year return period peak flood)

The design floods estimated were checked with available records for taking decision in adopting the design values. The available flood records (area-velocity method) on Sirsa at RD 28300, RD 18000, RD 10000, RD 5000, RD 0 and on tributaries Chikni, Khera and Pali Mahadev and the estimates of flood for these location were compared and observed to be close to estimated $Q_{25}$ (i.e., design flood for 25-year return period) values.
The design flood estimates for Sirsa (RD 28300 to RD 0) with $Q_{25}$ are higher than available flood records. On the other hand, for tributary catchments Chikni and Pali Mahadev the estimated flood discharges with $Q_{25}$ are higher than available flood record, while for Khera the estimated $220.05 \mathrm{~m}^{3} / \mathrm{s}$ with $Q_{25}$ is lower than the available record. However, one is not sure under what condition of storm the floods were computed for stream. The study thus 
indicates that, the flood estimation with rational formula for large catchments tend to yield higher peak rates as the method doesn't account for the channel losses and moderations and cautions its use with at most care and hydrologic judgments.

\section{Conclusions}

The study carried out for flood estimation is for an ungauged catchment adopting either recorded flood data from adjoining catchment or through indirect methods adopting empirical formula. The catchment factors for each of the river/ stream are used in deriving design storm duration in question. The derived design storm duration is used along with daily maximum (with return period 25-year, 50-year and 100 -year) in obtaining the design storm depth for each one of them. Based on the results of data analysis, the following conclusions were drawn from the study.

i. The $t_{c}$ estimates varied from 1-hour to 6-hours for the study river catchments.

ii. In absence of any observed flood hydrograph and short duration storm analysis for catchment, $t_{c}$ based estimation of design storm duration is a logical approach.

iii. The 25-year return period design flood estimates for Sirsa at RD 28300 to RD 0 are more than high flood discharges available, while for small catchments it is other way round.

iv. Based on the length of rainfall data used for the study (13-year) it is recommended to use results of FFA upto $Q_{25}$ floods. However, floods above this are subject to uncertainties and are to be used with caution.

v. The flood estimates for Sirsa river at RD 28300 to RD 0 have been computed with rational formula needs reliability checks as these are large size catchments, however these could still be used as preliminary estimates.

vi. The time compensation should be applied for flood estimates along a same river stretch to account for the variation of $\mathrm{t}_{\mathrm{c}}$ and the associated design storm depth.

\section{Acknowledgments}

The authors express their gratitude to Dr. (Mrs) V. V. Bhosekar, Director, CWPRS, for the encouragement in the work and also according permission to publish the paper. Sincere thanks to Shri. R.S. Jagtap, Joint Director, CWPRS for his valuable guidance during the work. The authors express thanks to Dr. R. G. Patil, Scientist E, River Hydraulics Division, CWPRS, for referring flood estimation component to the hydrometeorology division.

\section{References}

1. McCuen RH (2005) Hydrologic analysis and design, ( $3^{\text {rd }}$ edn). PrenticeHall, New York, USA.

2. Wong TSW (2005) Assessment of time of concentration formulas for overland flow. ASCE Journal of Irrigation and Drainage Engineering 131: 383-387.
3. Viessman W Jr, Lewis GL (2003) Introduction to hydrology, Pearson Education, New York, USA.

4. Sharifi S, Hosseini SM (2011) Methodology for identifying the best equations for estimating the time of concentration of watersheds in a particular region. ASCE Journal of Irrigation and Drainage Engineering 137: 712-719.

5. Gericke OJ, Smithers JC (2014) Review of methods used to estimate catchment response time for the purpose of peak discharge estimation. Hydrological Sciences Journal 59: 1935-1971.

6. NWRED (2013) Flood estimation in small catchments, The Natural Hazards Project - 5, Flood and Surface Water Flooding, Norwegian Water Resources and Energy Directorate (NWRED), Oslo, Norway.

7. Koutroulis AG, Tsanis IK (2010) A method for estimating flash flood peak discharge in a poorly gauged basin: Case study for the 13-14 January 1994 flood, Giofiros basin, Crete Greece. Journal of Hydrology 385: 150-164.

8. Ogden FL, Dawdy DR (2003) Peak discharge scaling in small Hortonian watershed. Journal of Hydrologic Engineering, 8: 64-73.

9. Poots AD, Cochrane SR (1979) Design flood estimation for bridges, culverts and channel improvement works on small rural catchments. Proceedings of the Institution of Civil Engineers, Part 1, 66: 663-666.

10. Rogger M, Kohl B, Pirkl H, Viglione A, Komma J et al. (2012) Runoff models and flood frequency statistics for design flood estimation in Austria- Do they tell a consistent story? Journal of Hydrology 456: $30-43$.

11. Adams CA (1989) Design flood estimations for ungauged rural catchments in Victoria. Technical Bulletin No. 38, Road Construction Authority, Victoria.

12. Grimaldi S, Petroselli A, Tauro F and Porfiri M (2012) Time of concentration: a paradox in modern hydrology. Hydrological Sciences Journal 57: 217-228.

13. FEMA (2010) Hydrologic models meeting the minimum requirement of NFIP, List of current nationally accepted hydrologic models by FEMA available on http://www.fema.gov/plan/prevent/fhm/en_hydro. shtm.

14. Viviroli D, Mittelbach H, Gurtz J, Weingartner R (2009) Continuous simulation for flood estimation in ungauged mesoscale catchments of Switzerland - Part II: Parameter regionalisation and flood estimation results. Journal of Hydrology 377: 208-225.

15. HSoER (2006) State of environment report. Department of environment, Science \& Technology, Government of Himachal Pradesh.

16. Gericke OJ (2011) Estimation of catchment response time for improved peak discharge estimation in South Africa. Ph.D. Thesis, University of KwaZulu-Natal, Pietermaritzburg.

17. Ramesh C, Vivekanandan N, Surwade KB, Bapat AD, Mathew FT et. al (2008) Extreme value analysis of rainfall in Mumbai region to aid estimation of severe flood. ISH Journal of Hydraulic Engineering 14: 102-117.

18. Surwade KB, Ramesh C, Kshirsagar MM, Govindan S (2009) Assessment of peak maximum rainfall for estimation of peak flood for ungauged Lakya catchment- A case study. Hydrology Journal, Indian Association of Hydrologists 32: 1-16.

19. USDA (2010) Time of concentration. National engineering handbook, USDA, Chapter 15, Section 4, Part 630 Washington, DC, USA.

20. CCP (1955) Culvert design, $\left(2^{\text {nd }}\right.$ edn). Sacramento: Department of Public Works, California Culvert Practice (CCP), Division of Highways.

21. Kerby WS (1959) Time of concentration for overland flow. Civil Engineering 29: 60-70. 


\section{Civil Engineering Research Journal}

22. Kirpich ZP (1940) Time of concentration of small agricultural watersheds. Civil Engineering 10: 362-368

23. Simas MJC (1996) Lag time characteristics in small watersheds in the United States. Ph.D. Dissertation, University of Arizona, USA.
24. CWC (1994) Flood estimation report for Western Himalayas-Zone 7. CWC Design Office Report No.: WH/22/1994, Central Water Commission (CWC), New Delhi, India.

Your next submission with Juniper Publishers will reach you the below assets

- Quality Editorial service

- Swift Peer Review

- Reprints availability

- E-prints Service

- Manuscript Podcast for convenient understanding

- Global attainment for your research

- Manuscript accessibility in different formats ( Pdf, E-pub, Full Text, Audio)

- Unceasing customer service

Track the below URL for one-step submission https://juniperpublishers.com/online-submission.php 